\title{
Effect of Different Nitrogen Rates on Productivity and Quality Traits of Wheat Cultivars
}

\author{
Dalia A.A. EL Hag ${ }^{\#}$ and Alaa. M.E.A. Shahein* \\ Agronomy Department, Faculty Agriculture, Kafrelsheikh University, Kafrelsheikh \\ and 'Seed Technology Research Department, Field Crops Research Institute, \\ Agricultural Research Center (ARC), Cairo, Egypt.
}

\begin{abstract}
HIS STUDY quantified the optimum doses of nitrogen $(\mathrm{N})$ fertilizers for wheat (Triticum aestivum L.). A field experiments were conducted in 2014/2015 and 2015/2016 seasons in a farm of the Faculty of Agriculture at Kafrelsheikh University. This study was laid out in a split plot design with three replications in RCBD. Wheat cultivars, Gemmeiza 11, Giza 171, Giza 168 and Sakha 94 were allocated in the main plots. Six different doses of nitrogen, i.e. 0, $25,50,75,100$ and $125 \mathrm{~kg} \mathrm{~N} /$ fad were used. The studied characters were agronomic and seeds technology traits. The results indicated that significant differences among the studied wheat cultivars in all agronomic studied and seeds technology were observed. Sakha 94 recorded the highest number of days to heading and maturity, plant height and Gemmeiza 11 recorded the highest values in number of spikes $/ \mathrm{m}^{2}$ in both seasons. Sakha 94 and Gemmeiza 11 recorded the highest values for 1000 grain weight in 2014/15 and 2015/16 seasons, respectively. Sakha 94 recorded the highest values for grain/spike in 2015/16 season. Sakha 94 recorded the highest values for EC in 2014/15, hectoliter, density, root length, and protein percentage in both seasons. Gemmeiza 11 superior the other cultivars for both of grain and straw yield and for EC in 2015/16 and for shoot length in both seasons. Giza 168 recorded the highest values for density in both seasons. Increases in nitrogen fertilizer increased significantly number of days to heading and maturity, plant height, spikes $/ \mathrm{m}^{2}$, grain/spike, grain and straw yield, while decreased 1000 grain weight. There were significant differences among $\mathrm{N}$ levels treatments regarding EC, hectoliter weight, density, root length, shoot length, dry weight and protein percentage in both seasons. Application of $100 \mathrm{~kg} \mathrm{~N} /$ fad resulted in higher values than other treatments for all traits except $\mathrm{EC}$ in both seasons were decreased.
\end{abstract}

Keywords: Wheat cultivars, Yield component, Nitrogen fertilizer, EC, Protein percentage.

\section{Introduction}

Wheat (Triticum aestivum L.) is the leading food crop in the world. It ranks first among the main four crops namely: rice, maize and barley. It occupies about $30 \%$ of the world cropping area (FAO, 2016). In Egypt, wheat is considered one of the more strategic grain crops. The cultivated area of wheat reached about 3.1 million faddan in 2015-2016 giving 8.2 million tons of grain, with a national average of about $18.1 \mathrm{ardab} / \mathrm{fad}$. However, the local consumption in the same year surpassed 14-15 million tons. Every year, Egypt imports about $55 \%$ of its wheat consumption to face the great needs of the high population increment and the shortage of production. Therefore, a great attention should be paid to overcome or minimize the gap between wheat production and consumption, thus increasing production per unit area appears to be the main objective of reducing the wheat gap. Increasing wheat yield per unit area could be attained by cultivating high-yielding cultivars and implement recommended cultural practices. Nitrogen fertilization had a vital role to increment yield component and yield attributes in various crops, especially wheat. Concerning the effect of nitrogen fertilizer levels on wheat grain yield and its attributes, Ahmed et al. (2009) showed that, addition of nitrogen fertilizer up to

"Correponding author email: dalia_elhag@yahoo.com DOI: 10.21608/agro.2017.1405.1070

C2017 National Information and Documentation Centre (NIDOC) 
(102 kg N/fad) increased significantly plant height, number of spikes $/ \mathrm{m}^{2}$, spike length, number of grain/spike, 100-grain weight, straw yield and grain yield ( $\mathrm{ard} / \mathrm{fad})$. Abdel-Hameed (2005), showed that, adding nitrogen fertilizer up to $100 \mathrm{~kg} \mathrm{~N} /$ fad, significant increase in plant height, number of spikes $/ \mathrm{m}^{2}$, number of grain/ spike, 1000 grain weight, straw yield and grain yield ( $\mathrm{ard} / \mathrm{fad})$ was observed. EL-Hawary \& Shahein (2015) indicated that adding nitrogen fertilizer up to $105 \mathrm{kgN} / \mathrm{fad}$, lead to increases in number of grain/spike, 1000-grain weight and grain yield ( $\mathrm{ard} / \mathrm{fad})$.

Many researchers (Moayedi et al., 2010; Sharshar, 2010; El hag, 2011; El hag, 2012; Kahloom et al., 2012; Mushtaq et al., 2012; Singh \& Singh, 2013; Omar et al., 2014; Kandil et al., 2016 and Hendawy, 2017) reported that day to maturity, maturity duration, grain filling rate, plant height, number of spike $\mathrm{m}^{-2}$, number of grain spike $\mathrm{e}^{-1}, 1000$-grain weight, harvest index and grain yield were significantly affected by wheat genotypes

\section{Materials and Methods}

Field experiments were conducted at Faculty of Agriculture- Kafrelsheikh University, during 2014/2015 and 2015/2016 seasons, to study the performance of four bread wheat cultivars (spring wheat) under different nitrogen fertilizer rates. The site is located at 30.94 North Latitude, 30.11 East Longitude with an elevation of about $6 \mathrm{~m}$ above sea level. Climatic elements of the area during the two growing seasons are presented in Table 1. A split plot design with three replications in Randomize Complete Block Design (RCBD) was used. The main plots were assigned to cultivars (Table 2) and six nitrogen fertilizer rates, i.e $0,25,50,75,100$ and $125 \mathrm{~kg} \mathrm{~N} / \mathrm{fad}$ were allocated in the sub plots. Application of nitrogen fertilizer were two third in the first irrigation (25 days from sowing) and the other one third in the second irrigation (50 days from sowing). The name and pedigree of these genotypes are presented in Table 2 .

TABLE 1a. Climatic elements of; air temperature $\left(T,{ }^{0} \mathrm{C}\right)$, mean relative humidity $(\mathrm{RH}, \%)$, wind speed $\left(\mathrm{U}_{2}, \mathrm{~m}\right.$. $\left.\mathrm{sec}^{-1}\right)$,evaporation pan $\left(\mathrm{EP}, \mathrm{mmd}^{-1}\right)$ and rainfall $(\mathrm{Rf}, \mathrm{mm})$ a. $\mathbf{1}^{\text {st }}$ season, 2014/15.

\begin{tabular}{|c|c|c|c|c|c|c|c|}
\hline \multirow[t]{2}{*}{ Month } & \multicolumn{3}{|c|}{$\mathbf{T}, \mathbf{C}^{0}$} & \multirow{2}{*}{ RH, \% } & \multirow{2}{*}{$\mathbf{U}_{2}$} & \multirow{2}{*}{$\mathrm{EP}, \mathrm{mm}, \mathrm{d}$} & \multirow{2}{*}{$\begin{array}{l}\text { Rf, mm } \\
\text { month }\end{array}$} \\
\hline & Max & Min & Mean & & & & \\
\hline Nov.2014 & 24.30 & 13.79 & 19.05 & 74.15 & 0.78 & 2.77 & 24.60 \\
\hline Dec.2014 & 22.27 & 9.72 & 16.00 & 76.05 & 0.53 & 1.72 & 5.70 \\
\hline Jan. 2015 & 18.79 & 6.46 & 12.63 & 74.60 & 0.82 & 2.70 & 52.55 \\
\hline Feb. 2015 & 19.01 & 7.65 & 13.33 & 74.75 & 0.84 & 2.90 & 38.80 \\
\hline Mar. 2015 & 22.69 & 11.69 & 17.19 & 7.59 & 1.01 & 3.23 & 15.25 \\
\hline Apr. 2015 & 25.64 & 13.70 & 19.69 & 63.40 & 1.11 & 6.07 & 35.85 \\
\hline Seasonal & 22.12 & 10.50 & 16.31 & 72.26 & 0.85 & 3.23 & 172.75 \\
\hline
\end{tabular}

TABLE 1b. Climatic elements of ; air temperature $\left(\mathrm{T},{ }^{0} \mathrm{C}\right)$, mean relative humidity $(\mathrm{RH}, \%)$, wind speed $\left(\mathrm{U}_{2}, \mathrm{~m}\right.$. $\mathrm{sec}^{-1}$ ), evaporation pan (EP, $\mathrm{mmd}^{-1}$ ) and rainfall (Rf, $\left.\mathrm{mm}\right) \mathbf{b . 2 ^ { \text { nd } }}$ season, 2015/16.

\begin{tabular}{|c|c|c|c|c|c|c|c|}
\hline \multirow[t]{2}{*}{ Month } & \multicolumn{3}{|c|}{$\mathbf{T}, \mathbf{C}^{\mathbf{o}}$} & \multirow{2}{*}{ RH, \% } & \multirow{2}{*}{$\mathbf{U}_{2}$} & \multirow{2}{*}{$\begin{array}{c}\text { EP, } \\
\text { mm, d }\end{array}$} & \multirow{2}{*}{$\begin{array}{c}\text { Rf, } \\
\text { mm month }\end{array}$} \\
\hline & $\operatorname{Max}$ & Min & Mean & & & & \\
\hline Nov.2015 & 24.75 & 14.42 & 19.59 & 75.62 & 0.58 & 2.44 & 52.4 \\
\hline Dec.2015 & 20.36 & 8.33 & 14.34 & 78.27 & 0.67 & 2.15 & 25.0 \\
\hline Jan. 2016 & 18.40 & 6.30 & 12.30 & 74.10 & 0.80 & 2.38 & 42.7 \\
\hline Feb. 2016 & 22.50 & 6.70 & 14.60 & 70.00 & 0.67 & 2.51 & - \\
\hline Mar. 2016 & 23.67 & 11.61 & 17.64 & 69.76 & 0.74 & 3.58 & 13.20 \\
\hline Apr. 2016 & 30.03 & 19.22 & 24.63 & 61.72 & 1.01 & 5.96 & - \\
\hline Seasonal & 23.29 & 11.10 & 17.19 & 71.58 & 0.79 & 3.17 & 133.3 \\
\hline
\end{tabular}


TABLE 2. Name and pedigree of four wheat cultivars used in this investigation.

\begin{tabular}{|c|c|c|}
\hline No. & Genotype & Pedigree \\
\hline 1 & Gemmeiza 11 & $\begin{array}{c}\text { BOW"S"'/KVZ'S'//7C/SER182/3/GIZA168/SAKHA61. } \\
\text { GM7892-2GM-1GM-2GM-1GM-OGM }\end{array}$ \\
\hline 2 & Giza 171 & $\begin{array}{l}\text { SAKHA } 93 \text { / GEMMEIZA } 9 \\
\text { S.6-1GZ-4GZ-1GZ-2GZ-0S. }\end{array}$ \\
\hline 3 & Giza 168 & $\begin{array}{c}\text { Mri/Buc//Seri } \\
\text { CM93046-8M-OY-OM-2Y-0B }\end{array}$ \\
\hline 4 & Sakha 94 & $\begin{array}{c}\text { Opta/Rayon//Kauz } \\
\text { CMBW90Y3180-OTOPM-3Y-010M-010Y-010Y-6M-OS }\end{array}$ \\
\hline
\end{tabular}

The preceding crop was rice (Oryza sativa, L) in both seasons

Composite soil sample was randomly collected from each site at the depths of 0 to $30 \mathrm{~cm}$ with 5 $\mathrm{cm}$ diameter auger before seed bed preparation in both seasons. These samples were analyzed for physical and chemical characteristics by following standard methods of analysis. Results of physical and chemical analysis in both seasons are shown in Table 3. The experimental field was fertilized with $15.5 \mathrm{~kg} \mathrm{P}_{2} \mathrm{O}_{5} /$ fad in the form of calcium superphosphate $\left(15.5 \% \mathrm{P}_{2} \mathrm{O}_{5}\right)$ during soil preparation.

Table 3. Physical and chemical properties of the soil at the experimental site during 2014/015 and 2015/2016 seasons.

\begin{tabular}{|c|c|c|c|c|c|c|c|c|}
\hline \multicolumn{9}{|c|}{ Character } \\
\hline \multicolumn{5}{|c|}{ Chemical analysis } & \multicolumn{4}{|c|}{ Physical characteristics } \\
\hline Seasons & $\begin{array}{c}\mathbf{N} \\
\text { (Available } \\
\text { ppm) }\end{array}$ & $\begin{array}{c}\text { P } \\
\text { (Available } \\
\text { ppm) }\end{array}$ & $\begin{array}{c}\text { K } \\
\text { (Available } \\
\text { ppm) }\end{array}$ & $\begin{array}{l}\text { Soil } \\
\text { pH }\end{array}$ & $\begin{array}{c}\text { Sand } \\
\%\end{array}$ & $\begin{array}{l}\text { Silt } \\
\%\end{array}$ & $\begin{array}{c}\text { Clay } \\
\%\end{array}$ & $\begin{array}{c}\text { Soil } \\
\text { texture }\end{array}$ \\
\hline $2014 / 15$ & 18 & 22.5 & 325 & 8.75 & 18.12 & 36.10 & 45.15 & clay \\
\hline $2015 / 16$ & 16 & 24.7 & 342 & 7.88 & 20.3 & 38.5 & 40.2 & clay \\
\hline
\end{tabular}

Seed rate was 350 seeds $/ \mathrm{m}^{2}$ of the four wheat cultivars were drilled in rows on flat land. Sowing was done on last week of November 26 and 30 in 2014 and 2015 seasons, respectively. Then, all plots were irrigated immediately. The sub-plot area was (6 rows $\times 20 \mathrm{~cm}$ apart $\times 3.5 \mathrm{~m})=4.2 \mathrm{~m}^{2}$ and harvest area was (4 rows x $3.5 \mathrm{~m}) 2.8 \mathrm{~m}^{2}$.

Nitrogen fertilizer in the form of urea $(46.5 \% \mathrm{~N})$. Other practices were done as usual recommended package.

\section{Studied traits}

A-Agronomic traits: Days to heading, days to maturity, plant height $(\mathrm{cm})$, number of spikes $/ \mathrm{m}^{2}$, number of grain/spike, 1000-grain weight (g), grain yield (ardab/fad), straw yield (ton/fad) and harvest index (HI) were estimated at harvest time (5 may 2015 and 8 may 2016).

\section{Quality traits}

Seedling vigor and the electrical conductivity (EC) of leached from four replicates of 50 seed weight and soaked in $250 \mathrm{ml}$ of distilled water for $24 \mathrm{~h}$ was measured in $\mu$-mhos using conductivity meter, were carried out under optimum conditions according to the international rules (I.S.TA, 1993). At the final count, ten of normal seedlings from each replicate were taken randomly to measure the shoot and radical length $(\mathrm{cm})$. Then, the seedlings were dried in a hot air oven at $80{ }^{\circ} \mathrm{C}$ for $12 \mathrm{~h}$ to obtain the seedling dry weight, which was determined according to the procedures reported in the seed vigor testing handbook (A.O.S.A, 1986). Relative density of seed was calculated according to Karmer \& Twigg (1962). The percentage of each of dry matter and protein was determined according to the procedures outlined in (A.O.A.C, 1990).

Statistical analysis:

All data collected for the two seasons was subjected to analysis of variance and means of treatments were compared using Duncan Multiple Range Test (Duncan, 1955). All statistical analyses were performed using analysis of variance technique by "MSTAT-C" (1990) computer software package. 


\section{$\underline{\text { Results and Discussion }}$}

Agronomic traits

Number of days to heading

The results presented in Table 4 show that there are highly significant differences among wheat cultivars for number of days to heading in both seasons. Sakha 94 recorded the highest number of days to heading. The variation among cultivars might reflect partially their different genetic backgrounds and environmental condition. These results were agreement with Gab Alla (2007), EL-Hawary \& Shahein (2015), Omar et al. (2014) and Kandil et al. (2016) who recorded that there were variation among wheat genotypes due to interaction between genotypes and environmental condition.

TABLE 4. Mean of number of days to heading, number of days to physiological mature and plant height (cm) as affected by wheat cultivars, nitrogen rate in 2014/2015 and 2015/2016 growing seasons.

\begin{tabular}{|c|c|c|c|c|c|c|}
\hline \multirow[t]{2}{*}{ Treatment } & \multicolumn{2}{|c|}{$\begin{array}{l}\text { No. days to heading } \\
\text { (day) }\end{array}$} & \multicolumn{2}{|c|}{$\begin{array}{c}\text { NO. of days to } \\
\text { physiological mature } \\
\text { (day) }\end{array}$} & \multicolumn{2}{|c|}{$\begin{array}{l}\text { Plant height } \\
\quad(\mathrm{cm})\end{array}$} \\
\hline & 2014-15 & 2015-16 & 2014-15 & 2015-16 & $2014-15$ & $2015-16$ \\
\hline \multicolumn{7}{|c|}{ Wheat cultivar } \\
\hline Gemmeiza 11 & $93.2 \mathrm{c} \dagger$ & $87.6 \mathrm{~b}$ & $144.2 \mathrm{ab}$ & $134.6 \mathrm{c}$ & $97.9 \mathrm{ab}$ & $87.6 \mathrm{bc}$ \\
\hline Giza 171 & $97.2 \mathrm{~b}$ & $87.8 \mathrm{~b}$ & $144.4 \mathrm{ab}$ & $133.7 \mathrm{~d}$ & $103.1 \mathrm{a}$ & $92.2 \mathrm{ab}$ \\
\hline Giza 168 & $94.8 b c$ & $84.8 \mathrm{c}$ & $142.5 b$ & $136.1 \mathrm{~b}$ & $91.6 b$ & $85.1 \mathrm{c}$ \\
\hline Sakha 94 & $100.8 \mathrm{a}$ & $90.0 \mathrm{a}$ & $146 \mathrm{a}$ & $143.2 \mathrm{a}$ & $105.7 \mathrm{a}$ & $97.4 \mathrm{a}$ \\
\hline $\mathrm{SE}^{\ddagger}$ & 0.541 & 0.438 & 0.630 & 0.161 & 2.55 & 1.155 \\
\hline \multicolumn{7}{|c|}{ Nitrogen fertilizer (kg N/fad) } \\
\hline 0 & $94.1 \mathrm{c}$ & $85.1 \mathrm{~d}$ & $139.8 \mathrm{e}$ & $134.4 d$ & $83.2 \mathrm{c}$ & $80.2 \mathrm{~d}$ \\
\hline 25 & $95.3 \mathrm{bc}$ & $85.1 \mathrm{~d}$ & $142.7 \mathrm{~d}$ & $134.8 \mathrm{~d}$ & $99.2 b$ & $87.5 \mathrm{c}$ \\
\hline 50 & $96.8 \mathrm{ab}$ & $87.6 \mathrm{c}$ & $144.9 \mathrm{c}$ & $135.9 \mathrm{c}$ & $102.5 \mathrm{ab}$ & $90.6 \mathrm{~b}$ \\
\hline 75 & $97.1 \mathrm{a}$ & $88.4 \mathrm{bc}$ & $145.2 \mathrm{bc}$ & $137.8 \mathrm{~b}$ & $105.1 \mathrm{a}$ & $92.5 b$ \\
\hline 100 & $97.8 \mathrm{a}$ & $89.1 \mathrm{ab}$ & $146.2 \mathrm{ab}$ & $138.8 \mathrm{a}$ & $103.8 \mathrm{a}$ & $96.1 \mathrm{a}$ \\
\hline 125 & $98.1 \mathrm{a}$ & $90.1 \mathrm{a}$ & $146.9 \mathrm{a}$ & $139.5 \mathrm{a}$ & $103.7 \mathrm{a}$ & $96.6 \mathrm{a}$ \\
\hline $\mathrm{SE}^{\ddagger}$ & 0.525 & 0.465 & 0.397 & 0.273 & 1.43 & 0.777 \\
\hline
\end{tabular}

(1.43 Duncan's multiple range test at $\mathrm{P} \leq 0.05$. $\mathrm{SE}^{\ddagger}=$ stander error

The effect of nitrogen fertilizer affected highly significantly on number of days to heading in 2014/15 and 2015/16 seasons. Application of 50, 75, 100 and $125 \mathrm{~kg} \mathrm{~N} / \mathrm{fad}$, recorded the highest number of days to heading without significant between them in 2014/15, and between 100 and $125 \mathrm{~kg} \mathrm{~N} / \mathrm{fad}$, in 2015/16 season. The availability of appropriate environmental conditions such as soil moisture, good nutrient conditions especially available when fertilization rate is recommended, and the resulting increase in the period of growth vegetative and increases the number of days from planting to maturity. This result is agreement with El Hag (2011), Abd EL-Hameed (2012), Hasina et al.,(2012), Gheith et al. (2013), Singh \& Singh (2013), Omar et al. (2014) and Kandil et al.(2016) who found that the increases in nitrogen fertilizer increased the vegetative period of wheat.

\section{Interaction effect:}

the interaction between wheat cultivars and nitrogen fertilizer not reach to significant effects in both seasons.

\section{Number of days to physiological mature}

Results in Table 4 show that there were significant and highly significant differences among wheat cultivars for number of days to maturity in both seasons. Sakha 94 recorded the highest number of days to maturity and latest one in both seasons. Difference in maturity dates among wheat genotypes may be due to the genetic constitution, which seriously affected by environmental conditions; also for different responses to the length of days and accumulation temperature. Many researchers such as AbdelHameed (2012), Gheith et al. (2013), Omar et al. (2014), EL-Hawary \& Shahein (2015) and 
Hendawy (2017) found the different variation among wheat genotypes.

The effect of nitrogen fertilizer was highly significant on number of days to maturity in 2014/15 and 2015/16 seasons. Application of 100 and $125 \mathrm{~kg} \mathrm{~N} / \mathrm{fad}$, recorded the highest number of days to maturity without significant among them in 2014/15, and 2015/16 seasons. Increases of nitrogen levels increased the period of vegetative growth and ripening time due to available of nutrition. Haile \& Nigussie-Dechassa (2013), Noureldin et al. (2013), Omar et al. (2014), Kandil et al.(2016) and Hendawy (2017) reported that the increase of nitrogen fertilizer increased number of days to physiological maturity.

The interaction between wheat cultivars and nitrogen fertilizer for number of days to physiological maturity reach to highly significant effects in 2015/16 season only. Sakha 94 record the highest values for number of days to physiological maturity with application of $125 \mathrm{~kg} \mathrm{~N} / \mathrm{fad}$ (Table 7) .

\section{Plant height $(\mathrm{cm})$}

The results presented in Table 4 showed that there were significant differences among wheat cultivars for plant height in 2014/15 and 2015/16 growing seasons. Sakha 94 record the tallest plant highest in both seasons, respectively. The differences between cultivars are often due to genetic makeup as well as the interaction between genetic makeup and environmental conditions. Also, the differences among cultivars due to variation of cell division rate of the stem especially in peduncle length. Mushtaq et al. (2012), Gheith et al. (2013), Singh \& Singh (2013), Omar et al. (2014), EL-Hawary \& Shahein (2015), Omar et al. (2014) and Kandil et al. (2016) found significant variation among wheat cultivars.

Nitrogen fertilizer was highly significant effect on plant height in 2014/15 and 2015/16 seasons. Application of 50, 75, 100 and 125 $\mathrm{kg} \mathrm{N} / \mathrm{fad}$ in 2014/15 and 100 and $125 \mathrm{~kg} \mathrm{~N} /$ fad, recorded the tallest wheat plant without significant difference between them. Increases of nitrogen levels increased the vegetative growth due to available of nutrition and photosynthesis, more of active enzyme and chlorophyll. Singh \& Singh (2013), Omar et al. (2014), Kandil et al.(2016) and Hendawy (2017) were noticed that increases nitrogen fertilizer increased plant height due to rule of nitrogen on plant for cell division and elongation between inter nodes.
The interaction between wheat cultivars and nitrogen fertilizer was highly significant effects for plant height in 2015/16 season only. Sakha 94 recorded the tallest plant with fertilizer by $125 \mathrm{~kg}$ N/fad (Table 7)

\section{Number of spikes $/ \mathrm{m}^{2}$}

Regarded for wheat cultivars, Results presented in Table 5 show that there were highly significant differences effects among wheat cultivars for number of spikes $/ \mathrm{m}^{2}$ in both seasons. Gemmeiza 11 and Giza 171 recorded the highest number of spikes $/ \mathrm{m}^{2}$ in $2014 / 15$ and 2015/16 seasons, respectively. Difference in number of spikes $/ \mathrm{m}^{2}$ among wheat genotypes may be due to the genetic constitution, which seriously affected by environmental conditions under normal irrigation and nitrogen fertilizer. Such results were found by Mushtaq et al. (2012), Gheith et al. (2013), Noureldin et al. (2013), Haile \& NigussieDechassa (2013), Omar et al. (2014), EL-Hawary \& Shahein (2015) and Hendawy (2017).

Results in Table 5 shows that number of spikes $/ \mathrm{m}^{2}$ was highly significant affected by nitrogen fertilizer in 2014/15 and 2015/16 seasons. Application of 100 and $125 \mathrm{~kg} \mathrm{~N} / \mathrm{fad}$, recorded the highest number of spikes $/ \mathrm{m}^{2}$ in $2014 / 15$ and 125 $\mathrm{kg} \mathrm{N} / \mathrm{fad}$, in 2015/16. Increases of nitrogen levels increased number of spikes $/ \mathrm{m}^{2}$ due to available nutrition. This results is in agreement with this obtained byb Noureldin et al. (2013), Omar et al. (2014), EL-Hawary \& Shahein (2015), Kandil et al. (2016) and Hendawy (2017) who found that increases nitrogen fertilizer increased number of spikes $/ \mathrm{m}^{2}$.

The interaction between wheat cultivars and nitrogen fertilizer not reach to significant effects in both seasons.

\section{Thousand grain weight $(g)$}

The results presented in Table 5 showed highly significant differences among wheat cultivars for thousand grain weight in both seasons. Sakha 94 and Gemmeiza 11 recorded the highest thousand grain weight in 2014/15 and 2015/16 seasons. Thousand grain weight is the most important characteristic of variation between cultivars and varieties and feedback to genotype gene. These results are in harmony with those found by Sharshar (2010), Abdel-Hameed (2012), Hasina et al. (2012), Mushtaq et al. (2012), Gheith et al. (2013), Noureldin et al. (2013), Omar et al. (2014), EL-Hawary \& Shahein (2015) and Hendawy (2017). 
TABLE 5. Mean of number of spikes/m², thousand grain weight and number of grain/spike as affected by wheat cultivars, nitrogen rate in 2014/15 and 2015/16 growing seasons.

\begin{tabular}{|c|c|c|c|c|c|c|}
\hline \multirow[t]{2}{*}{ Treatment } & \multicolumn{2}{|c|}{ No. spikes $/ \mathrm{m}^{2}$} & \multicolumn{2}{|c|}{$\begin{array}{l}\text { Thousand grain } \\
\text { weight (gm) }\end{array}$} & \multicolumn{2}{|c|}{ No. grain/spike } \\
\hline & 2014-15 & 2015-16 & 2014-15 & 2015-16 & 2014-15 & 2015-16 \\
\hline \multicolumn{7}{|c|}{ Wheat cultivar: } \\
\hline Gemmeiza 11 & $400.9 \mathrm{a}^{\dagger}$ & $267.6 \mathrm{ab}$ & $44.4 \mathrm{ab}$ & $42.8 \mathrm{a}$ & 58.7 & $54.9 \mathrm{c}$ \\
\hline Giza 171 & $355.0 \mathrm{~b}$ & $282.8 \mathrm{a}$ & $42.8 \mathrm{bc}$ & $41.2 b$ & 60.3 & $60.6 b$ \\
\hline Giza 168 & $295.8 \mathrm{c}$ & $207.3 \mathrm{c}$ & $41.7 \mathrm{c}$ & $35.7 \mathrm{~d}$ & 59.9 & $56.9 \mathrm{bc}$ \\
\hline Sakha 94 & $392.2 \mathrm{a}$ & $250.3 b$ & $45.7 \mathrm{a}$ & $36.4 \mathrm{c}$ & 60.3 & $68.7 \mathrm{a}$ \\
\hline $\mathrm{SE}^{\ddagger}$ & 6.89 & 6.88 & 0.36 & 0.09 & - & 1.11 \\
\hline \multicolumn{7}{|c|}{ Nitrogen fertilizer ( $\mathrm{kg} \mathrm{N} / \mathrm{fad})$} \\
\hline 0 & $246.3 \mathrm{e}$ & $185.2 \mathrm{f}$ & $46.0 \mathrm{a}$ & $41.4 \mathrm{a}$ & $43.3 b$ & $49.9 \mathrm{e}$ \\
\hline 25 & $310.8 \mathrm{~d}$ & $210.8 \mathrm{e}$ & $45.6 \mathrm{a}$ & $40.4 b$ & $54.5 \mathrm{ab}$ & $55.9 \mathrm{~d}$ \\
\hline 50 & $341.3 \mathrm{c}$ & $239.3 d$ & $43.9 b$ & $38.8 \mathrm{c}$ & $59.1 \mathrm{ab}$ & $58.1 \mathrm{~d}$ \\
\hline 75 & $407.8 \mathrm{~b}$ & $259.4 \mathrm{c}$ & $43.2 \mathrm{~b}$ & $38.6 \mathrm{c}$ & $64.5 \mathrm{a}$ & $61.9 \mathrm{c}$ \\
\hline 100 & $425.8 \mathrm{ab}$ & $300.0 \mathrm{~b}$ & $41.8 \mathrm{c}$ & $38.1 \mathrm{~d}$ & $66.8 \mathrm{a}$ & $65.6 \mathrm{~b}$ \\
\hline 125 & $434 \mathrm{a}$ & $317.3 \mathrm{a}$ & $41.3 \mathrm{c}$ & $36.7 \mathrm{e}$ & $70.7 \mathrm{a}$ & $70.3 \mathrm{a}$ \\
\hline $\mathrm{SE}^{\ddagger}$ & 7.32 & 5.30 & 0.265 & 0.264 & 0.838 & 0.806 \\
\hline
\end{tabular}

Data in Table 5 revealed that thousand grain weight was highly significant affected by nitrogen fertilizer in 2014/15 and 2015/16 seasons. Application lower nitrogen fertilizer (zero and $25 \mathrm{~kg} \mathrm{~N} / \mathrm{fad}$ ) in 2014/15 and (zero) in 2015/16 produced the highest values of grain weight. Increases of nitrogen levels decreased 1000 grain-weight due to increases nitrogen produced more tillers and more grain/spikes thus decreased thousand grain weight. These results agreement with Omar et al. (2014) and EL-Hawary \& Shahein (2015) and Hendawy (2017).

The interaction between wheat cultivars and nitrogen fertilizer did not reach to significant effects in both seasons.

\section{Number of grain/spike}

There were highly significant differences among wheat cultivars for number of grain/spike in 2015/16 season Table 5. Sakha 94 recorded the highest number of grain/spike. Number of grain/ spike is one of the most important components of the yield after the number of spikes per unit area and these different from one to other cultivars depending on the genetic makeup. Moayedi et al. (2010), Hasina et al. (2012), Gheith et al. (2013), Singh \& Singh (2013), Omar et al. (2014), EL-
Hawary \& Shahein (2015), El hag (2016) and Hendawy (2017), found significant variation among wheat cultivars.

The effect of nitrogen fertilizer was highly significant for number of grain/spike in 2014/15 and 2015/16 seasons. Application of $125 \mathrm{~kg} \mathrm{~N} / \mathrm{fad}$, produced the highest value of number of grain/ spike in both seasons, respectively. Increases of nitrogen levels increased the number of grain/ spikes due to increases manly number of spikelets/ spike under favorable condition especially mineral nutrition and moisture content in soil. The results are harmony with El Hag (2011), AbdelHameed (2012), Gheith et al. (2013), Singh \& Singh (2013), Omar et al. (2014), EL-Hawary \& Shahein (2015), Kandil et al.(2016) and Hendawy (2017).

The interaction between wheat cultivars and nitrogen fertilizer were highly significant in 2015/16 season only. Sakha 94 recorded the highest number of grain/spike with application $125 \mathrm{~kg} \mathrm{~N} /$ fad (Table 7).

\section{Grain yield (ton/fad)}

The results presented in Table 6 show a highly significant affect of wheat cultivars on grain yield in both seasons. Gemmeiza 11 and Giza 
171 produced the highest grain yield in the first and second seasons, respectively. The highest grain yield was due to yield component, $i e$, number of spikes $/ \mathrm{m}^{2}$, grain $/$ spike and thousand grain-weigh. Several researchers, Abdel-Hameed
(2012), Hasina et al. (2012), Omar et al. (2014), EL-Hawary \& Shahein (2015), Kandil et al. (2016) and Hendawy (2017) reported that yield components were play important role effect for grain yield.

TABLE 6. Mean of grain yield (ton/fad) straw yield (ton/fad) and harvest index $\%$ as affected by wheat cultivars, nitrogen fertilizer in 2014/2015 and 2015/2016 growing season.

\begin{tabular}{|c|c|c|c|c|c|c|}
\hline \multirow[t]{2}{*}{ Treatment } & \multicolumn{2}{|c|}{ Grain yield (ton/fad) } & \multicolumn{2}{|c|}{ Straw yield (ton/fad) } & \multicolumn{2}{|c|}{ HI\% } \\
\hline & 2014-15 & 2015-16 & 2014-15 & 2015-16 & 2014-15 & $\begin{array}{c}2015- \\
16\end{array}$ \\
\hline \multicolumn{7}{|c|}{ Wheat cultivar } \\
\hline Gemmeiza 11 & $3.437 \mathrm{a} \uparrow$ & $2.323 b$ & $5.260 \mathrm{a}$ & $4.218 b$ & 39.7 & $35.2 b$ \\
\hline Giza 171 & $2.770 \mathrm{~b}$ & $2.488 \mathrm{a}$ & $4.840 \mathrm{ab}$ & $4.451 \mathrm{a}$ & 36.7 & $35.2 b$ \\
\hline Giza168 & $2.621 \mathrm{~b}$ & $2.198 \mathrm{c}$ & $4.401 b$ & $3.652 \mathrm{c}$ & 37.7 & $37.4 \mathrm{a}$ \\
\hline Sakha 94 & $2.872 \mathrm{~b}$ & $1.914 d$ & $4.883 \mathrm{ab}$ & $3.425 \mathrm{c}$ & 37.3 & $35.3 b$ \\
\hline $\mathrm{SE}^{\ddagger}$ & 0.112 & 0.022 & 0.108 & 0.055 & -- & 0.164 \\
\hline \multicolumn{7}{|c|}{ Nitrogen fertilizer (kg N/fad) } \\
\hline 0 & $1.727 \mathrm{e}$ & $1.318 \mathrm{f}$ & $2.677 \mathrm{e}$ & $3.223 \mathrm{e}$ & 38.6 & $32.2 \mathrm{f}$ \\
\hline 25 & $2.492 \mathrm{~d}$ & $1.780 \mathrm{e}$ & $4.049 \mathrm{~d}$ & $3.453 \mathrm{~d}$ & 38.4 & $33.6 \mathrm{e}$ \\
\hline 50 & $2.940 \mathrm{c}$ & $2.153 \mathrm{~d}$ & $4.755 \mathrm{c}$ & $3.904 \mathrm{c}$ & 38.2 & $35.2 \mathrm{~d}$ \\
\hline 75 & $3.223 b$ & $2.432 \mathrm{c}$ & $5.325 \mathrm{~b}$ & $4.171 \mathrm{~b}$ & 37.7 & $36.5 \mathrm{c}$ \\
\hline 100 & $3.456 \mathrm{~b}$ & $2.650 \mathrm{~b}$ & $5.900 \mathrm{a}$ & $4.275 b$ & 37.0 & $38.0 \mathrm{~b}$ \\
\hline 125 & $3.712 \mathrm{a}$ & $3.103 \mathrm{a}$ & $6.372 \mathrm{a}$ & $4.593 \mathrm{a}$ & 37.0 & $39.2 \mathrm{a}$ \\
\hline SE & 0.085 & 0.028 & 0.19 & 0.062 & - & 0.181 \\
\hline
\end{tabular}

The results presented in Table 6 revealed that nitrogen fertilizer influenced highly significant for grain yield during both seasons. Application of $125 \mathrm{~kg} \mathrm{~N} /$ fad recorded the highest value for grain yield in 2014/15 and 2015/16 seasons. The highest of grain yield are due mainly to highest number of fertile tillers and number of grain/ spike. The results are in harmony with El Hag (2011), Abdel-Hameed (2012), Hasina et al. (2012), Gheith et al. (2013), Haile \& NigussieDechassa (2013), Noureldin et al. (2013), Singh \& Singh (2013), Omar et al. (2014), Kandil et al. (2016) and Hendawy (2017).

The interaction between wheat cultivars and nitrogen fertilizer was highly significant in 2015/16 season. Results presented in Table 6 indicate that wheat cultivar Gemmeiza 11 produced the highest grain yield with application $125 \mathrm{~kg} \mathrm{~N} /$ fad (Table 7).

\section{Straw yield (ton/fad)}

Results presented in Table 6 showed that straw yield was a highly significant affected by wheat cultivars in both seasons. Gemmeiza 11 and Giza 171 produced the highest straw yield in the first and second seasons. The highest straw yield was increases due to increase yield component specially, number of fertile tillers and plant height. Several researchers, Sharshar (2010), El Hag (2011), Abdel-Hameed (2012), Gheith et al. (2013), Haile \& Nigussie-Dechassa (2013), Omar et al. (2014) and EL-Hawary \& Shahein (2015) found significant variation due to wheat cultivars.

The results presented in Table 6 for straw yield reveal that nitrogen fertilizer influenced highly significant straw yield during both seasons. Application of 100 and $125 \mathrm{~kg} \mathrm{~N} /$ fad recorded the highest straw yield (5.900 and $6.372 \mathrm{ton} / \mathrm{fad})$ in 2014/15 and 75, 100 and $125 \mathrm{~kg} \mathrm{~N} / \mathrm{fad,} \mathrm{recorded}$ the highest straw yield without significant differences among them in 2015/16 seasons. 
Increase straw yield returns in the application of 100 and $125 \mathrm{~kg} \mathrm{~N} / \mathrm{fad}$ as a result of the availability of soil moisture and thus the necessary nutrients for plants during the growing season to increase the yield components in addition to the increase in dry matter accumulated. These results are in agreement with those reported by Noureldin et al. (2013), Singh \& Singh (2013), Omar et al. (2014), EL-Hawary \& Shahein (2015), Kandil et al.(2016) and Hendawy (2017).

The interaction between wheat cultivars and nitrogen fertilizer was significant and highly significant in 2014/15 and 2015/16 seasons, respectively. Results presented in Table 7 indicated that wheat cultivar Sakha 94 and Giza 171 produced the highest straw yield under 125 $\mathrm{kg} \mathrm{N} /$ fad (Table7 ).

TABLE 7. Mean of number of days to maturity, plant height, number of grain/spike, grain yield and straw yield as affected by interaction between wheat cultivars and nitrogen rate.

\begin{tabular}{|c|c|c|c|c|c|c|c|}
\hline \multirow{2}{*}{\multicolumn{2}{|c|}{ Treatment }} & \multirow{3}{*}{$\begin{array}{c}\begin{array}{c}\text { No. days to } \\
\text { maturity }\end{array} \\
\\
130\end{array}$} & \multirow{3}{*}{$\begin{array}{r}\begin{array}{r}\text { Plant } \\
\text { height }\end{array} \\
\mathbf{2} \\
81.7\end{array}$} & \multirow{3}{*}{$\begin{array}{c}\begin{array}{c}\text { No. grain/ } \\
\text { spike }\end{array} \\
/ 16 \\
43.3\end{array}$} & \multirow{3}{*}{$\begin{array}{c}\begin{array}{c}\text { Grain yield } \\
\text { ton/fad }\end{array} \\
2.633\end{array}$} & \multicolumn{2}{|c|}{$\begin{array}{l}\text { Straw yield } \\
\text { ton/fad }\end{array}$} \\
\hline & & & & & & \multirow{2}{*}{$\begin{array}{c}\mathbf{2 0 1 4} / \mathbf{1 5} \\
3.703\end{array}$} & \multirow{2}{*}{$\frac{\mathbf{2 0 1 5} / \mathbf{1 6}}{3.6}$} \\
\hline \multirow{6}{*}{ 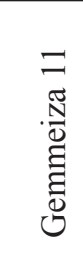 } & 0 & & & & & & \\
\hline & 25 & 133 & 88.3 & 51.2 & 3.171 & 5.424 & 3.935 \\
\hline & 50 & 135 & 91.3 & 55.1 & 3.438 & 5.394 & 4.189 \\
\hline & 75 & 135 & 90.0 & 58.11 & 3.689 & 5.263 & 4.452 \\
\hline & 100 & 136 & 90.0 & 57.5 & 3.787 & 5.736 & 4.408 \\
\hline & 125 & 137 & 84.3 & 64.2 & 3.905 & 6.042 & 4.722 \\
\hline \multirow{6}{*}{$\begin{array}{l}\bar{N} \\
\stackrel{\tilde{N}}{0} \\
\stackrel{0}{0}\end{array}$} & 0 & 131 & 81.3 & 46.9 & 1.274 & 2.268 & 2.715 \\
\hline & 25 & 132 & 90.7 & 56.4 & 2.38 & 3.752 & 4.205 \\
\hline & 50 & 135 & 89.3 & 56.5 & 2.87 & 4.816 & 4.928 \\
\hline & 75 & 136 & 95.0 & 61.2 & 3.136 & 5.838 & 5.000 \\
\hline & 100 & 137 & 97.0 & 66.5 & 3.318 & 6.160 & 5.068 \\
\hline & 125 & 138 & 100.0 & 76.1 & 3.647 & 6.209 & 5.087 \\
\hline \multirow{6}{*}{ 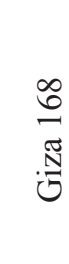 } & 0 & 131 & 74.3 & 46.4 & 1.218 & 1.974 & 2.095 \\
\hline & 25 & 133 & 78.0 & 49.9 & 2.079 & 3.283 & 3.213 \\
\hline & 50 & 135 & 85.0 & 53.5 & 2.660 & 4.102 & 3.682 \\
\hline & 75 & 136 & 84.7 & 59.3 & 2.891 & 4.725 & 3.921 \\
\hline & 100 & 137 & 92.3 & 65.8 & 3.276 & 6.020 & 4.109 \\
\hline & 125 & 138 & 96.0 & 66.7 & 3.605 & 6.307 & 4.505 \\
\hline \multirow{6}{*}{$\begin{array}{l}\text { J } \\
\tilde{J} \\
\frac{\mathbb{J}}{\pi} \\
\tilde{n}\end{array}$} & 0 & 138 & 83.3 & 63.1 & 1.785 & 2.765 & 2.768 \\
\hline & 25 & 140 & 93.0 & 66.2 & 2.338 & 3.738 & 2.78 \\
\hline & 50 & 142 & 96.7 & 67.2 & 2.793 & 4.711 & 2.933 \\
\hline & 75 & 145 & 100.3 & 68.8 & 3.178 & 5.474 & 3.613 \\
\hline & 100 & 146 & 105.0 & 72.5 & 3.444 & 5.684 & 3.842 \\
\hline & 125 & 147 & 106.0 & 74.1 & 3.696 & 6.930 & 4.659 \\
\hline \multicolumn{2}{|c|}{ LSD 0.05} & 1.56 & 4.44 & 4.60 & 0.164 & 1.09 & 0.354 \\
\hline \multicolumn{2}{|l|}{$\mathrm{SE}^{\ddagger}$} & 0.546 & 1.554 & 1.612 & 0.058 & 0.381 & 0.124 \\
\hline
\end{tabular}

Harvest index (\%)

The results in Table 6 for harvest index indicated that there were highly significant deference's among wheat cultivars in 2015/16 season. The maximum harvest index was recorded by Giza 168 (37.4) in 2015/16 season. These differences among wheat cultivars due to variation ratio of grain yield and biological yield of cultivars. These results are harmony with those reported by Moayedi et al. (2010), El Hag (2011), Omar et al. (2014), EL-Hawary \& Shahein (2015), El Hag (2016) and Hendawy (2017).

Nitrogen fertilizer influenced highly significant for harvest index in the 2015/16 season. Application $125 \mathrm{~kg} \mathrm{~N} / \mathrm{fad}$, recorded the highest value of harvest index (39.2). This results were obtained by several researchers e.g. El Hag (2011), Hasina et al. (2012), Omar et al. (2014), 
EL-Hawary \& Shahein (2015) and Hendawy (2017).

The interaction effect between wheat cultivars and nitrogen fertilizer were insignificant on harvest index in both seasons.

Quality traits

EC

The results in Table 8 for EC indicated that there were highly significant and significant deference's among wheat cultivars in both seasons, respectively. The maximum EC was recorded by Sakha 94, Giza 168 and Gemmeiza 11 (10.62, 10.48 and 10.35) in 2014/15 and Gemmeiza 11 (11.25) in 2015/16. These results are harmony with those reported by Hasina et al. (2012) and Hawary \& Shahein (2015).

TABLE 8 . Mean of EC, hectoliter, density as affected by wheat cultivars and different nitrogen rates in 2014/15 and $2015 / 16$ seasons.

\begin{tabular}{|c|c|c|c|c|c|c|}
\hline \multirow{2}{*}{ Treatment } & \multicolumn{2}{|c|}{ EC } & \multicolumn{2}{|c|}{ Hectoliter } & \multicolumn{2}{|c|}{ Density } \\
\hline & 2014/15 & 2015/16 & $2014 / 15$ & $2015 / 16$ & 2014/15 & 2015/16 \\
\hline \multicolumn{7}{|c|}{ Wheat cultivars } \\
\hline Gemmeiza 11 & $10.35 \mathrm{a}$ & $11.25 \mathrm{a}$ & $87.29 \mathrm{~d}$ & $86.89 \mathrm{c}$ & $1.186 \mathrm{c}$ & $1.138 \mathrm{c}$ \\
\hline Giza 171 & $9.24 \mathrm{~b}$ & $9.43 b$ & $88.48 \mathrm{c}$ & $88.28 b$ & $1.253 \mathrm{a}$ & $1.254 \mathrm{~b}$ \\
\hline Giza 168 & $10.48 \mathrm{a}$ & $10.38 \mathrm{bc}$ & $91.65 b$ & $90.08 \mathrm{a}$ & $1.250 \mathrm{a}$ & $1.263 \mathrm{ab}$ \\
\hline Sakha 94 & $10.62 \mathrm{a}$ & $10.91 \mathrm{c}$ & $92.23 \mathrm{a}$ & $90.50 \mathrm{a}$ & $1.225 \mathrm{~b}$ & $1.267 \mathrm{a}$ \\
\hline $\mathrm{SE}^{\ddagger}$ & 0.158 & 0.057 & 0.034 & 0.206 & 0.002 & 0.002 \\
\hline \multicolumn{7}{|c|}{ Nitrogen fertilizer (kg N/fad) } \\
\hline 0 & $11.78 \mathrm{a}$ & $11.25 \mathrm{a}$ & $87.72 \mathrm{f}$ & $86.50 \mathrm{e}$ & $1.073 \mathrm{f}$ & $1.080 \mathrm{f}$ \\
\hline 25 & $10.62 b$ & $10.81 \mathrm{~b}$ & $88.93 \mathrm{e}$ & $88.17 \mathrm{~d}$ & $1.135 \mathrm{e}$ & $1.135 \mathrm{e}$ \\
\hline 50 & $10.16 \mathrm{c}$ & $10.64 \mathrm{bc}$ & $89.69 d$ & $90.08 \mathrm{c}$ & $1.213 \mathrm{~d}$ & $1.211 \mathrm{~d}$ \\
\hline 75 & $10.03 \mathrm{c}$ & $10.46 \mathrm{c}$ & $90.34 \mathrm{c}$ & $90.50 \mathrm{c}$ & $1.259 \mathrm{c}$ & $1.273 \mathrm{c}$ \\
\hline 100 & $9.63 \mathrm{~d}$ & $10.02 \mathrm{~d}$ & $91.09 \mathrm{~b}$ & $91.75 b$ & $1.312 \mathrm{~b}$ & $1.313 b$ \\
\hline 125 & $8.83 \mathrm{e}$ & $9.77 \mathrm{e}$ & $91.71 \mathrm{a}$ & $92.58 \mathrm{a}$ & $1.380 \mathrm{a}$ & $1.371 \mathrm{a}$ \\
\hline $\mathrm{SE}^{\ddagger}$ & 0.0469 & 0.079 & 0.0483 & 0.208 & 0.002809 & 0.003 \\
\hline
\end{tabular}

${ }^{\top}$ Mean values in the same column for each trait followed by the same lower-case letter are not significantly different according to Duncan's multiple range test at $\mathrm{P} \leq 0.05$. $\mathrm{SE}^{\ddagger}=$ stander error.

Nitrogen fertilizer was influenced highly significant for EC in the 2014/15 and 2015/16 seasons. Application $125 \mathrm{~kg} \mathrm{~N} / \mathrm{fad}$, recorded the lowest values of EC (8.83 and 9.77). These results are in agreement with those found by Ejaz et al. (2002), Warreich et al. (2002), Haile \& NigussiseDechassa (2013) and Hawary \& Shahein (2015).

The interaction effect between wheat cultivars and nitrogen fertilizer were highly significant and significant on EC in both seasons, respectively. Giza 168 and Gemmeiza 11 were recorded the highest values (13.63 and 12.05) under lowest rate of fertilizer in 2014/15 and 2015/16 seasons, respectively (Table 9).

Hectoliter

The results in Table 8 for hectoliter indicated that there were highly significant differences among wheat cultivars in both seasons. The maximum hectoliter (92.23 and 93.11) were recorded by Sakha 94, meanwhile Gemmeiza 11 recorded the lowest value (87.89 and 86.89) in both seasons, respectively. These results are in accordance with those obtained by Hasina et al. (2012) and Hawary \& Shahein (2015). 
TABLE 9. Mean of EC, hectoliter and density as affected by interaction between wheat cultivars and nitrogen rate in 2014/15and 2015/16.

\begin{tabular}{|c|c|c|c|c|c|c|c|}
\hline \multirow{2}{*}{\multicolumn{2}{|c|}{ Treatment }} & \multicolumn{2}{|c|}{ EC } & \multicolumn{2}{|c|}{ Hectoliter } & \multicolumn{2}{|c|}{ Density } \\
\hline & & $2014 / 15$ & $2015 / 16$ & $2014 / 15$ & $2015 / 16$ & $2014 / 15$ & $2015 / 16$ \\
\hline \multirow{5}{*}{ 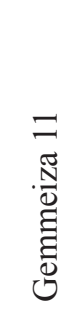 } & 0 & 12.40 & 12.05 & 84.47 & 83.33 & 1.057 & 1.033 \\
\hline & 25 & 10.88 & 11.40 & 86.66 & 84.67 & 1.090 & 1.077 \\
\hline & 50 & 10.07 & 11.40 & 87.01 & 86.67 & 1.137 & 1.110 \\
\hline & 75 & 9.91 & 11.50 & 87.63 & 87.33 & 1.183 & 1.150 \\
\hline & 100 & 9.60 & 10.63 & 88.40 & 88.33 & 1.243 & 1.180 \\
\hline \multirow{7}{*}{$\begin{array}{l}\vec{\Xi} \\
\underset{\mathbb{N}}{\tilde{N}}\end{array}$} & 125 & 9.26 & 10.50 & 89.60 & 91.00 & 1.403 & 1.280 \\
\hline & 0 & 8.65 & 10.40 & 86.82 & 84.67 & 1.167 & 1.167 \\
\hline & 25 & 8.86 & 9.80 & 87.50 & 86.33 & 1.197 & 1.190 \\
\hline & 50 & 9.14 & 9.57 & 88.15 & 87.67 & 1.257 & 1.233 \\
\hline & 75 & 9.37 & 9.23 & 88.91 & 88.33 & 1.273 & 1.260 \\
\hline & 100 & 9.61 & 8.90 & 89.57 & 91.00 & 1.300 & 1.330 \\
\hline & 125 & 9.80 & 8.67 & 89.94 & 91.67 & 1.327 & 1.343 \\
\hline \multirow{6}{*}{ 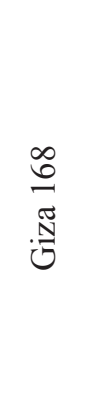 } & 0 & 13.63 & 11.13 & 89.28 & 87.33 & 1.030 & 1.060 \\
\hline & 25 & 11.62 & 10.80 & 90.56 & 89.33 & 1.147 & 1.130 \\
\hline & 50 & 10.63 & 10.50 & 91.63 & 92.33 & 1.220 & 1.230 \\
\hline & 75 & 10.28 & 10.30 & 92.21 & 92.67 & 1.293 & 1.340 \\
\hline & 100 & 9.36 & 9.83 & 92.86 & 93.33 & 1.383 & 1.360 \\
\hline & 125 & 7.34 & 9.70 & 93.39 & 93.67 & 1.427 & 1.457 \\
\hline \multirow{6}{*}{ 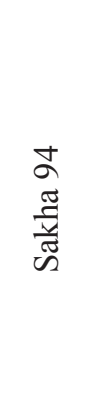 } & 0 & 12.45 & 11.40 & 90.31 & 90.67 & 1.037 & 1.060 \\
\hline & 25 & 11.11 & 11.23 & 91.02 & 92.33 & 1.107 & 1.143 \\
\hline & 50 & 10.77 & 11.10 & 91.99 & 93.67 & 1.237 & 1.270 \\
\hline & 75 & 10.54 & 10.80 & 92.59 & 93.67 & 1.287 & 1.343 \\
\hline & 100 & 9.94 & 10.70 & 93.54 & 94.33 & 1.320 & 1.383 \\
\hline & 125 & 8.92 & 10.20 & 93.92 & 94.00 & 1.363 & 1.403 \\
\hline \multicolumn{2}{|c|}{ F test } & $*$ & $* *$ & $* *$ & $* *$ & $* *$ & $* *$ \\
\hline \multicolumn{2}{|c|}{ LSD 0.05} & 0.848 & 0.326 & 0.276 & 1.192 & 0.0165 & 0.0165 \\
\hline \multicolumn{2}{|c|}{$\mathrm{SE}^{\ddagger}$} & 0.296 & 0.159 & 0.417 & 0.502 & 0.002 & 0.023 \\
\hline
\end{tabular}


Nitrogen fertilizer significantly affected for hectoliter in the 2014/15 and 2015/16 seasons. Application $125 \mathrm{~kg} \mathrm{~N} / \mathrm{fad}$, recorded the highest values of hectoliter ( 91.71 and 92.58) in both seasons, respectvely. These results are in agreement with those found by Hasina et al. (2012), Haile \& Nigussise-Dechassa (2013) and Hawary \& Shahein (2015).

The interaction effect between wheat cultivars and nitrogen fertilizer were highly significant on hectoliter in both seasons. Sakha 94 was recorded the highest values (93.92) under application of $125 \mathrm{~kg} \mathrm{~N} / \mathrm{fad}$, in 2014/15 and (94.33) under 100 $\mathrm{kg} \mathrm{N} /$ fad, 2015/16 seasons (Table 9).

\section{Density}

The results in Table 8 for density indicated that there were significant differences among wheat cultivars in both seasons. The maximum density was recorded by Giza 168 (1.25 and 1.263) in both seasons, respectively, meanwhile Gemmeiza 11 recorded the lowest values (1.186 and 1.138) in both seasons, respectively. These results are found by Hasina et al. (2012) and Hawary \& Shahein (2015).
Nitrogen fertilizer influenced significantly for density in the 2014/15 and 2015/16 seasons. Application $125 \mathrm{~kg} \mathrm{~N} / \mathrm{fad}$, recorded the highest value (1.38 and 1.37) of density in both seasons, respectively. These results are in agreement with those found by Ejaz et al. (2002), Warreich et al. (2002), Hasina et al. (2012) and Hawary \& Shahein (2015).

The interaction effect between wheat cultivars and nitrogen fertilizer was significantly affected on density in both seasons. Giza 168 was recorded the highest values (1.427 and 1.457) under application of $125 \mathrm{~kg} \mathrm{~N} / \mathrm{fad}$, in 2014/15 and 2015/16 seasons (Table 9).

Root length

The results in Table 10 for root length indicated that there were significantly deference's among wheat cultivars in both seasons. The maximum root length was recorded by Sakha 94 and Gemmeiza 11 (10.40 and 10.17) in 2014/15 and 2015/16 seasons, respectively. These results are agreement with those obtained by Hasina et al. (2012) and Hawary \& Shahein (2015).

Table 10 . Mean of root length $(\mathrm{cm})$, shoot length $(\mathrm{cm})$, dry weight $(\mathrm{gm})$ and protein $\%$ as affected by cultivars and different nitrogen rate in $2014 / 15$ and $2015 / 16$ seasons.

\begin{tabular}{|c|c|c|c|c|c|c|c|c|}
\hline & \multicolumn{2}{|c|}{ Root length (cm) } & \multicolumn{2}{|c|}{ Shoot length (cm) } & \multicolumn{2}{|c|}{ Dry weight (gm) } & \multicolumn{2}{|c|}{ Protein $\%$} \\
\hline & $2014 / 15$ & $2015 / 16$ & $2014 / 15$ & $2015 / 16$ & $2014 / 15$ & $2015 / 16$ & $2014 / 15$ & $2015 / 16$ \\
\hline \multicolumn{9}{|c|}{ Wheat cultivars } \\
\hline $\begin{array}{l}\text { Gemmeiza } \\
11\end{array}$ & $10.40 \mathrm{a}^{\dagger}$ & $10.17 \mathrm{a}$ & $11.40 \mathrm{a}$ & $11.48 \mathrm{a}$ & $0.146 \mathrm{a}$ & $0.150 \mathrm{a}$ & $9.8 \mathrm{~d}$ & $10.0 \mathrm{~d}$ \\
\hline Giza 171 & $9.09 \mathrm{c}$ & $9.23 c$ & $9.53 \mathrm{~d}$ & $10.31 \mathrm{c}$ & $0.115 b c$ & $0.131 b$ & $10.1 \mathrm{c}$ & $10.3 \mathrm{c}$ \\
\hline Giza 168 & $9.41 \mathrm{~b}$ & $9.49 \mathrm{~b}$ & $9.96 \mathrm{c}$ & $10.53 c$ & $0.120 b$ & $0.125 \mathrm{c}$ & $10.1 \mathrm{~b}$ & $10.5 b$ \\
\hline Sakha 94 & $10.43 a$ & $10.23 \mathrm{a}$ & $10.49 b$ & $10.98 b$ & $0.108 \mathrm{c}$ & $0.113 d$ & $10.7 \mathrm{a}$ & $10.7 \mathrm{a}$ \\
\hline SE & 0.026 & 0.035 & 0.029 & 0.061 & 0.002 & 0.0001 & 0.0024 & 0.028 \\
\hline \multicolumn{9}{|c|}{ Nitrogen fertilizer (kg N/fad) } \\
\hline 0 & $8.11 \mathrm{f}$ & $8.30 \mathrm{f}$ & $9.06 f$ & $9.09 \mathrm{f}$ & $0.102 d$ & $0.111 d$ & $9.3 \mathrm{f}$ & $9.7 \mathrm{f}$ \\
\hline 25 & $8.71 \mathrm{e}$ & $8.89 \mathrm{e}$ & $9.54 \mathrm{e}$ & $9.67 \mathrm{e}$ & $0.114 \mathrm{c}$ & $0.119 \mathrm{~d}$ & $9.5 \mathrm{e}$ & $10.0 \mathrm{e}$ \\
\hline 50 & $9.59 \mathrm{~d}$ & $9.61 d$ & $9.97 \mathrm{~d}$ & $10.63 d$ & $0.122 b$ & $0.129 \mathrm{c}$ & $9.7 d$ & $10.1 \mathrm{~d}$ \\
\hline 75 & $10.18 \mathrm{c}$ & $10.19 \mathrm{c}$ & $10.55 \mathrm{c}$ & $11.16 \mathrm{c}$ & $0.125 b$ & $0.135 b c$ & $10.2 \mathrm{c}$ & $10.4 \mathrm{c}$ \\
\hline 100 & $10.92 b$ & $10.54 b$ & $11.16 \mathrm{~b}$ & $11.97 \mathrm{~b}$ & $0.130 \mathrm{~b}$ & $0.140 \mathrm{ab}$ & $11.1 \mathrm{~b}$ & $10.8 \mathrm{~b}$ \\
\hline 125 & $11.47 \mathrm{a}$ & $11.16 \mathrm{a}$ & $11.79 \mathrm{a}$ & $12.43 \mathrm{a}$ & $0.140 \mathrm{a}$ & $0.145 \mathrm{a}$ & $11.4 \mathrm{a}$ & $11.4 \mathrm{a}$ \\
\hline $\mathrm{SE}^{*}$ & 0.0437 & 0.030 & 0.094 & 0.074 & 0.0028 & 0.0028 & 0.035 & 0.035 \\
\hline
\end{tabular}

$\uparrow$ Mean values in the same column for each trait followed by the same lower-case letter are not significantly different according to Duncan's multiple range test at $\mathrm{P} \leq 0.05$. $\mathrm{SE}^{\star}=$ stander error. 
Nitrogen fertilizer influenced significantly for root length in the 2014/15 and 2015/16 seasons. Application of $125 \mathrm{~kg} \mathrm{~N} / \mathrm{fad}$, recorded the tallest root length (11.47 and 11.16) in both seasons, respectively. Similar results were obtained by Ejaz et al. (2002), Haile \& Nigussise-Dechassa (2013) and Hawary \& Shahein (2015).

The interaction between wheat cultivars and nitrogen fertilizer were significantly for root length in both seasons. Sakha 94 and Gemmeiza 11 were recorded the highest values (12.11 and 11.40) under highest rate of fertilizer in 2014/15 and 2015/16 seasons, respectively (Table 11).

\section{Shoot length}

The results in Table 10 for shoot length indicated that there were significantly differences among wheat cultivars in both seasons. The maximum shoot length were recorded by Gemmeiza 11 (11.40 and 11.48) in both seasons, respectively. These results are in accordance with those obtained by Hasina et al. (2012) and Hawary \& Shahein (2015).

Nitrogen fertilizer had highly significant effect for shoot length in the 2014/15 and 2015/16 seasons. Increases nitrogen fertilizer rate gradually increased shoot length. Application 125 $\mathrm{kg} \mathrm{N} / \mathrm{fad}$, recorded the tallest root length (11.79 and 12.43) in both seasons, respectively. Similar results were obtained by Hasina et al. (2012) and Haile \& Nigussise-Dechassa (2013) and Hawary \& Shahein (2015).

The interaction effect between wheat cultivars and nitrogen fertilizer were highly significant for shoot length in both seasons. Gemmeiza 11 was recorded the tallest shoot under highest rate of fertilizer (12.96 and 12.80) in both seasons, respectively (Table 11).

\section{Dry weight}

The results in Table 10 indicated that there were significant deference's among wheat cultivars for dry weight in both seasons. The highest weight of dry weight (0.146 and 0.150$)$ was recorded by Gemmeiza 11 in both seasons, respectively. These results are in harmony with those obtained by Hasina et al. (2012) and Hawary \& Shahein (2015).

Nitrogen fertilizer influenced highly significant of dry weight in the 2014/15 and 2015/16 seasons. Application $125 \mathrm{~kg} \mathrm{~N} / \mathrm{fad}$, recorded the highest value of dry weight $(0.140$ and 0.145 ) in both seasons, respectively. These results are in agreement with those found by Ejaz et al. (2002), Hasina et al. (2012), Haile \& Nigussise-Dechassa (2013) and Hawary \& Shahein (2015).

The interaction effect between wheat cultivars and nitrogen fertilizer were highly significant on dry weight in both seasons. Gemmeiza 11 was recorded the highest values under application of $125 \mathrm{~kg} \mathrm{~N} / \mathrm{fad},(0.168$ and 0.175$)$ in both seasons, respectively (Table 11).

\section{Protein \%}

The results in Table 10 indicated that protein percentage was highly significant differences among wheat cultivars in both seasons. The maximum protein \% was recorded by Sakha 94 (10.7 and $10.4 \%$ ) in both seasons, respectively. These results are in obtained with those obtained by Hasina et al. (2012) and Hawary \& Shahein (2015).

Nitrogen fertilizer influenced highly significant of protein \% in the 2014/15 and 2015/16 seasons. Application $125 \mathrm{~kg} \mathrm{~N} / \mathrm{fad}$, recorded the highest values of protein \% (11.4 and $11.4 \%$ ) in both seasons, respectively. Similar were obtained by Warreich et al. (2002), Hasina et al. (2012), Haile \& Nigussise-Dechassa (2013) and Hawary \& Shahein (2015).

The interaction effect between wheat cultivars and nitrogen fertilizer were highly significant on protein \% in both seasons. Sakha 94 was recorded the highest values under application of $125 \mathrm{~kg} \mathrm{~N} /$ fad (12.5 and 11.60 in both seasons, respectively (Table 11$)$.

\section{Conclusions}

This study has demonstrated that yields and yield components of the four improved bread wheat cultivars Gemmeiza 11, Giza 171, Giza 168 and Sakha94. Gemmeiza 11 and Giza 171 surprise the other cultivars for yield and yield components. $\mathrm{N}$ application rates of 100 and 125 $\mathrm{kg} \mathrm{fad}^{-1}$ were maximized significantly yield and yield components in both seasons, respectively, compared to the other lower nitrogen treatment. Therefore, Gemmeiza 11 and Giza 171, increase production of grain yield, straw yield, number of tillers $/ \mathrm{m}^{-2}$ and number of grain/spike with application of $\mathrm{N}$ at 100 and $125 \mathrm{~kg} \mathrm{fed}^{-1}$. It may be concluded that planting Gemmeiza 11 and Giza 171 with application $100 \mathrm{~kg} \mathrm{~N} /$ fad could be considered for obtaining higher yield of wheat production. 
TABLE 11. Mean of root length, shoot length, dry weight and protein $\%$ as affected by interaction between wheat cultivars and nitrogen rate in 2014/15 and 2015/16.

\begin{tabular}{|c|c|c|c|c|c|c|c|c|c|}
\hline \multirow[b]{2}{*}{ Cult. } & \multirow{2}{*}{$\begin{array}{c}\mathbf{N} \\
\text { fert. }\end{array}$} & \multicolumn{2}{|c|}{ Root length } & \multicolumn{2}{|c|}{ Shoot length } & \multicolumn{2}{|c|}{ Dry weight } & \multicolumn{2}{|c|}{ Protein \% } \\
\hline & & $2014 / 15$ & $2015 / 16$ & $2014 / 15$ & $2015 / 16$ & $2014 / 15$ & $2015 / 16$ & $2014 / 15$ & $2015 / 16$ \\
\hline \multirow{6}{*}{ 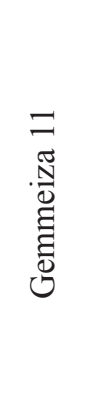 } & 0 & 8.82 & 8.50 & 9.68 & 9.80 & 0.127 & 0.131 & 9.2 & 9.4 \\
\hline & 25 & 9.31 & 9.23 & 10.22 & 10.17 & 0.135 & 0.132 & 9.3 & 9.6 \\
\hline & 50 & 10.39 & 10.23 & 11.28 & 11.50 & 0.143 & 0.147 & 9.3 & 9.7 \\
\hline & 75 & 10.95 & 10.40 & 11.91 & 11.93 & 0.147 & 0.156 & 9.5 & 9.7 \\
\hline & 100 & 11.32 & 11.23 & 12.35 & 12.67 & 0.154 & 0.161 & 10.8 & 10.6 \\
\hline & 125 & 11.59 & 11.43 & 12.96 & 12.80 & 0.168 & 0.175 & 10.9 & 10.9 \\
\hline \multirow{6}{*}{$\frac{\mathbb{I}}{\mathbb{N}}$} & 0 & 7.40 & 8.43 & 8.35 & 8.93 & 0.101 & 0.116 & 9.3 & 9.5 \\
\hline & 25 & 8.57 & 8.70 & 9.28 & 9.50 & 0.111 & 0.127 & 9.3 & 9.8 \\
\hline & 50 & 8.84 & 8.97 & 9.52 & 10.07 & 0.114 & 0.131 & 9.8 & 10.1 \\
\hline & 75 & 9.15 & 9.33 & 9.70 & 10.43 & 0.117 & 0.136 & 10.4 & 10.5 \\
\hline & 100 & 9.98 & 9.53 & 9.86 & 11.20 & 0.122 & 0.138 & 10.8 & 10.7 \\
\hline & 125 & 10.57 & 10.43 & 10.47 & 11.70 & 0.124 & 0.139 & 11.0 & 11.5 \\
\hline \multirow{6}{*}{ 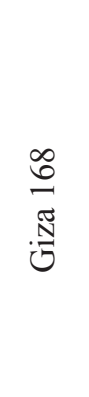 } & 0 & 7.00 & 7.07 & 8.74 & 7.97 & 0.097 & 0.102 & 9.1 & 9.7 \\
\hline & 25 & 7.40 & 7.90 & 8.96 & 8.63 & 0.110 & 0.118 & 9.4 & 10.2 \\
\hline & 50 & 9.42 & 9.43 & 9.22 & 10.47 & 0.122 & 0.128 & 9.8 & 10.3 \\
\hline & 75 & 10.33 & 10.47 & 10.57 & 11.33 & 0.124 & 0.130 & 10.5 & 10.6 \\
\hline & 100 & 10.73 & 10.67 & 10.86 & 12.10 & 0.128 & 0.135 & 10.9 & 11.0 \\
\hline & 125 & 11.60 & 11.37 & 11.39 & 12.67 & 0.140 & 0.139 & 11.1 & 11.5 \\
\hline \multirow{6}{*}{ 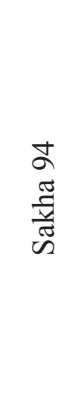 } & 0 & 9.23 & 9.20 & 9.45 & 9.67 & 0.085 & 0.095 & 9.6 & 10.0 \\
\hline & 25 & 9.57 & 9.73 & 9.71 & 10.37 & 0.098 & 0.100 & 9.8 & 10.4 \\
\hline & 50 & 9.73 & 9.80 & 9.85 & 10.50 & 0.109 & 0.109 & 10.0 & 10.5 \\
\hline & 75 & 10.31 & 10.57 & 10.03 & 10.93 & 0.113 & 0.120 & 10.5 & 10.8 \\
\hline & 100 & 11.65 & 10.73 & 11.56 & 11.90 & 0.115 & 0.125 & 11.8 & 11.0 \\
\hline & 125 & 12.11 & 11.40 & 12.35 & 12.53 & 0.127 & 0.127 & 12.5 & 11.6 \\
\hline \multicolumn{2}{|c|}{$\mathrm{F}$ test } & $* *$ & $* *$ & $* *$ & $* *$ & $* *$ & $* *$ & $* *$ & $* *$ \\
\hline \multicolumn{2}{|c|}{ LSD 0.05} & 0.250 & 0.542 & 0.281 & 0.423 & 0.423 & 0.0165 & 0.0165 & 0.208 \\
\hline \multicolumn{2}{|c|}{$\mathrm{SE}^{\ddagger}$} & 0.023 & 0.189 & 0.090 & 0.148 & 0.006 & 0.006 & 0.006 & 0.071 \\
\hline
\end{tabular}




\section{References}

A.O.A.C. (1990) "Official Methods of Analysis". The Association of Official Analytical Chemists $15^{\text {th }}$ (Edition, Published by Association of Official Analytical Chemists, Arrington, Virginia, USA.

A.O.S.A. (1986) Association of Official Seed Analysis. "Seed Vigor Testing Hand Book", No., 32, p. 1 .

Abd EL-Hameed, L.M. (2005) Response of two newly released bread wheat cultivars to different nitrogen and phosphorus fertilizer levels. The $1^{\text {st }}$ Conf. Cereal Crops, June 20 $0^{\text {th }}, 21^{\text {th }}, 2005$ (Alexandria, Egypt).

Abd EL-Hameed, L.M. (2012) Response of four new bread wheat (Triticum aestivum L.) cultivars to nitrogen fertilizer levels under sprinkler irrigation system in sandy soil. Egyptian J. Agric. 34(1), $1-17$.

Ahmed, Seham M.M., Abdul Galil, A.A., Basha, H.A. and Mowafy, A.A.E. (2009) Response of wheat to fertilization under sandy soil conditions. Zagazig J. Agric. Res. 36(4), 1045-1067.

Duncan, B.D. (1955) Multiple range and multiple F test. Biometric, 11, $1-42$.

Ejaz, A.W., Basra, S.M.A., Ahmad, N., Ahmed, R. and Aftab, M. (2002) Effect of nitrogen on grain quality and vigor in wheat (Triticum aestivum L.). Int. J. Agri. Biol. 4(4), 517-520.

El Hag, Dalia A. A. (2012) Effect of planting date and nitrogen level on yield and quality of bread and durum wheat. Ph D. Thesis, Kafrelsheikh Univ., Egypt.

El Hag, DaliaA. A. (2016) Effect of seeding rates on yield and yield components of two bread wheat cultivars. J. Agric. Res. Kafrelsheikh Univ. J. 42(1), 29-43.

El Hag, Walaa A. A. (2011) Evaluation of some cultivars and Lines of bread wheat under low input. M. Sc. Thesis, Kafrelsheikh Univ., Egypt.

EL-Hawary, M.N.A. and Shahein, Alaa M.E.A. (2015) Response of some wheat cultivars to sowing on bed under different nitrogen levels on some agronomic and quality traits. J. Agr. Kafrelsheikh. Univ. 41(4), 1340-1354

FAOSTAT (2016) (C) FAO Statistics Division, March 2016.

Gab Alla, M.M. (2007) Effect of irrigation numbers on some varieties and strains of wheat M.Sc. Thesis, Kafrelsheikh Univ., Egypt.

Gheith, E.M.S., El-Badry, Ola Z. and Wahid, S.A. (2013) Sowing dates and nitrogen fertilizer levels effect on grain yield and its components of different wheat cultivars. Agron. Dept., Fac. of Agric., Cairo, Univ., Egypt, 9(5), 176-181.

Haile, D. and Nigussie-Dechassa, R. (2013) Seed and seedling performance of bread wheat (Triticum aestivum L.) as influenced by rate and in-season nitrogen application. American. J. Experimental Agric. 3(4), 857-870.

Hasina, G., Saeed, A.Z., Khan, B., Nigar, S., Said, A. and Khalil, S.K. (2012) Determination of seed quality tests of wheat varieties under the response of different sowing dates and nitrogen fertilization. Pak. J. Nutr. 11(1), 34-37.

Hendawy, H.A.E. (2017) Effect of different nitrogen and phosphorus rates on the performance of wheat cultivars. M. Sc. Thesis, Kafrelsheikh Univ., Egypt.

I.S.T.A. (1993) International Rules for Seed Testing. Seed Sci. and Technol. 21, 24-46.

Kahloom, M.H., Iqbal, M.F., Farooq, M., Ali, L., Fiaz, M. and Ahmad, I. (2012) A comparison of conservation technologies and traditional techniques for sowing of wheat. J. Animal Plant Sci. 22(3), 827-830.

Kandil, A. A., Sharief, A.E.M., Seadh, S.E. and Altai, D.S.K. (2016) Role of humic acid and amino acids in limiting loss of nitrogen fertilizer and increasing productivity of some wheat cultivars grown under newly reclaimed sandy soil. Int. J. Adv. Res. Biol. Sci. 3(4), 123-136

Karmer, A. and Twigg, B.A. (1962) Fundamentals of quality control for the food industry. AVI Publishing Co. West. Port, CT, pp.512.

Moayedi, A.A., Boyce, A.N. and Barakbah, S.S. (2010) The Performance of durum and bread wheat cultivars associated with yield and yield component under different water deficit conditions. Australian Journal of Basic and Applied Sciences, 4(1), 106-113.

MSTATC (1990) A Microcomputer program for design manegment and analysis of agronomic research experiments, Michigan State Univ.

Mushtaq, A., Liaqat, A., Masood, Q.W. and Ali, M.A. (2012) Bed planting: a new crop establishment method for wheat (Triticum aestivum L.) in cottonwheat cropping system of southern Punjab. Int. J. Agric. Appl. Sci. 4(1), 8-14.

Noureldin, Nemat A.H.S., Ashmawy- Saudy, F. and Saed, H.M. (2013) Grain yield response index of bread wheat cultivars as influenced by nitrogen levels. Annals of Agricultural Science, 58(2). 147152.

Omar, A.M., Mohamed, A.A.E., Sharsher, M.S.A. and 
El Hag, Walaa A.A. (2014) Performance of some bread wheat genotypes under water regime and sowing methods. J. Agric. Res. Kafrelsheikh Univ. 40(2), 327-341

Sharshar, A.M. (2010) Combining ability and heterosis for bread wheat under stress and normal irrigation treatments. M. Sc. Thesis, Kaferelsheikh Univ., Egypt.

Singh, D. and Singh, R.A. (2013) Effect of wheat (Triticum aestivum $\mathrm{L}$.) varieties to sowing methods and time of nitrogen application in late sown condition in Eastern Uttar. Pradesh Research. $J$. Agric.Sci. 4(3), 341-346.

Warreich, E.J., Basra, S.M.A., Ahmad, N.R. and Aftab, M. (2002) Effect of Ahmed nitrogen on grain quality and vigor in wheat (Triticum aestivum L.) Int. J. Agric. Bio. 4,517-520.

(Received 30 / 7 / 2017; accepted 7 / 11 / 2017)

\section{تأثير التسميد بمعدلات مختلفة من النيتروجين على إنتاجية وجودة أصناف القـح}

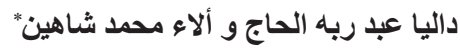

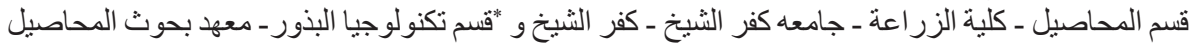

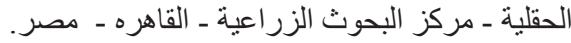

أجريت هذه الدر اسة لتقدير مدى استجابة أصناف القمح لجر عات عالبة من السماد النبتروجينى. أجريت تجربة

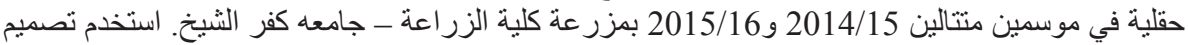

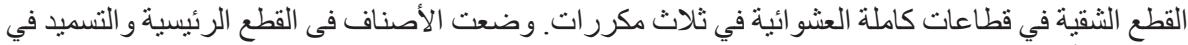

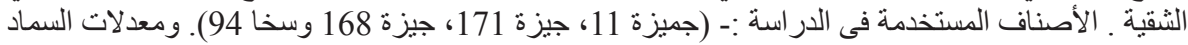

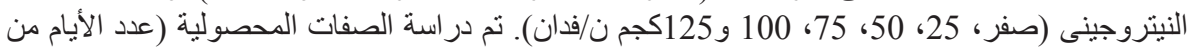

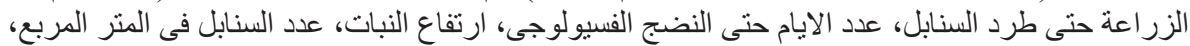

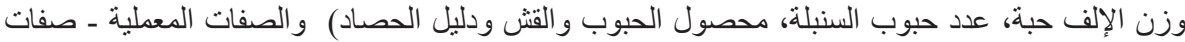

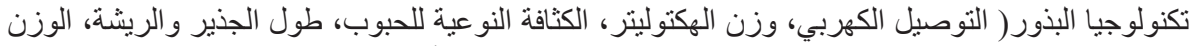

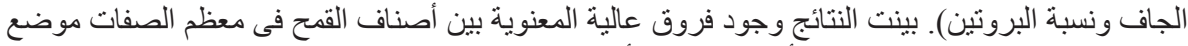

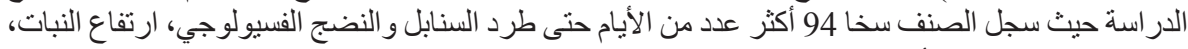

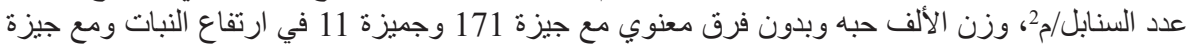

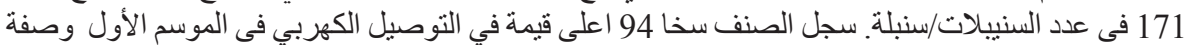

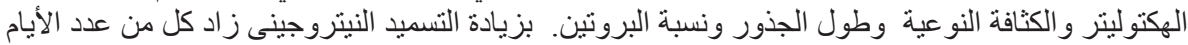

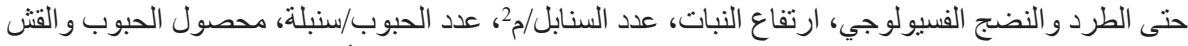

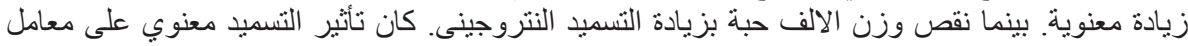

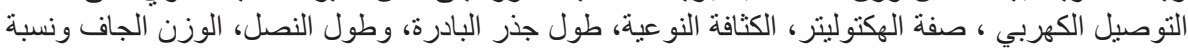

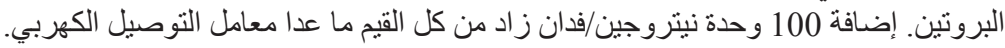

